\title{
Developing a Measure to Predict Fame and Success
}

\author{
Monroe Mann \\ Break Diving, Inc. a 501(c)(3), Port Chester, USA \\ Jonathan Rich \\ California Southern University, Costa Mesa, USA
}

\begin{abstract}
While a desire for fame and success is universal, little research has been devoted to discovering traits associated with their attainment. Mann (2016) completed a qualitative study of factors that contribute to success. Grounded theory was used to extract themes from interviews of successful entertainers who were asked to describe the factors that contributed to their success. There were three phases to the process of achieving success: Orientation, Approach, and Maintenance. Building on this framework, the present research developed a test to measure characteristics associated with fame and success. A sample was gathered online; 311 participants responded to 186 attitudinal items and 10 additional validity items, and also provided information about their level of success and notoriety in highly competitive endeavors. Item analysis reduced the number of items to 58 attitudinal items on seven scales: Doing What You Love, Desire for Fame, Determination, Focus, Business Skills, Maverick Tendencies, and Lifelong Learner Interest. Substantial correlations were found between the scales and self-reported measures of success and fame.
\end{abstract}

Keywords: success, fame, psychological test, creativity, entertainment

\section{Developing a Measure to Predict Fame and Success}

The desire to achieve notoriety, success, and fame, is universal. There are perceived benefits to fame that lead many to believe that achieving it is worth high levels of effort and risk-taking. Jayson (2007) points out that, in response to social and economic pressures, wealth and fame have become primary goals for most young adults. But despite the common urge to seek fame and success, there is virtually no psychological research that uncovers key personality characteristics and attitudes that are associated with their attainment.

Research to date has focused on factors associated with a desire for fame and success rather than their attainment. To a significant degree, this desire is seen as motivated by pathological rather than healthy attributes. Noser and Zeigler (2014) found that unstable self-esteem was associated with a desire for fame, and they suggest that fame is sought simply to gain external validation. Maltby (2010) also identified compensation for low self-esteem as a motivating factor, although he saw high levels of drive, altruism and a desire for an opulent lifestyle as also supporting the desire for fame. Greenwood, Long, and Dal Cin (2013) found a desire for fame associated with narcissism and a need to belong.

Further, there has been little research on the characteristics of successful people on their rise to the top, and never before has a psychometric instrument been developed to measure and help develop one's potential

Monroe Mann, Ph.D., JD, MBA, ME, LLM, Executive Director, Break Diving, Inc. a 501(c)(3), Port Chester, USA.

Jonathan Rich, Ph.D., Adjunct Faculty, School of Behavioral Sciences, California Southern University, Costa Mesa, USA. 
for such success that may lead to fame. While success that leads to fame has been elusive to most people, this study aims to develop a measure that can predict success (and possibly subsequent fame), as well as a measure that individuals can use to better equip themselves both practically and psychologically for success.

\section{Success Is Elusive}

In late 2012, an article in the publication Monitor on Psychology - a publication of the American Psychological Association (APA) - pointed out the need for a new division of the APA called the Entertainment Division. This new division would focus on and be of service to those who study psychological issues in entertainment and those who counsel clients who are a part of the entertainment industry (American Psychological Association, 2012). The simple fact that only now is entertainment being deemed a separate category of psychological inquiry demonstrates a clear need for more studies like ours into the elusive nature of success in risky pursuits. Indeed, any type of study that focuses exclusively on the psychological aspects of pursuing and succeeding in a risky career venture would help to fill the gap in the literature that has existed for far too long.

In particular, the art and science of becoming successful remains largely elusive. Common opinions about what it takes to succeed invariably mention talent, connections, and/or luck. As an example of the "rare and few" nature of the entertainment business, in 2004 a total of 40,826 paid union on-screen television and film roles were cast (Screen Actors Guild, 2004), while the total membership of the entire Screen Actors Guild boasted approximately 180,000 members (Union Facts, 2013). A simple calculation shows us then that in 2004, no more than $22 \%$ of the entire "professional" film and television actor workforce in the United States earned any money. Of those, few made a career out of acting, and still fewer achieved a level of fame. It is common knowledge that the statistics are equally $\operatorname{dim}$ from the worlds of television, politics, books, sports, entrepreneurship, etc. The fact is that becoming successful and making a living in risky fields is, at best, barely attainable.

Nonetheless, there are those across the nation (and the world) who do in fact persist in the face of daunting odds and succeed in make a living from such pursuits; those who against all odds, somehow manage to stand out from the crowd (O’Brien \& Hagen, 2013), and become successful (Sternberg, 2003).

\section{The Term "Successful"}

Five studies by O'Brien and Hagen (2013) show that winning within large groups of competitors is associated with more positive emotional reactions than winning among small groups. However, those who do not win tend to suffer more as well. In the race towards show business or entertainment success, despite participants invariably tending to fail more than they succeed (Screen Actors Guild, 2004), many continue to persist. The term "success" defined by O'Brien and Hagen (2013) means being chosen for a special distinction from a pool of many possible winners. The term "successful intelligence" is defined as the ability to achieve success in life consistent with one's personal standards, within one's socio-cultural context (Sternberg, 2003). In this study, then, the term "success" will be defined as "achieving one's career aspirations" (i.e., pay, status, and accomplishments) "based on standards of achievement widely accepted as typical of the common socio-cultural context" (i.e., resulting in some type of special distinction from a pool of many possible winners and the ability to support oneself financially solely from proceeds earned in that domain).

\section{Success in Entertainment and Other Fields}

In general, there are not many research articles discussing the makeup of or the path to becoming a success 
in risky endeavors. For example, an intriguingly titled article "The Actor's Opportunity" (Meyer, Dighe, \& Van Epps, 2014) ends up merely talking about "actors" as opposed to "reactors". Other articles discuss arts and business together, but not in a way that relates to the research question under review. For example, in Mucha (2005), the researcher states, "the elements that come together to capture the hearts and minds of audiences for years are the same elements that must come together to result in businesses that are built to last" (p. 68). Mucha (2005) studied what a traditional business can learn from the arts about success, whereas this present study investigates how and why those in risky ventures become and stay successful. Second, Mucha (2005) discusses what businesses can learn from the artistic side of the arts. This study discusses processes including improvisation, acting skills, comfort when speaking to audiences, interpersonal communication skills, etc. While the article does discuss the success elements of a successful theater organization by noting that successful Broadway theater owners/producers must ask questions such as who is our competition, what is the economic climate, and what is the current pulse of our target market, these are all questions that focus on the producer as a key ingredient in the success of the theater production as a whole; there is no discussion of what makes the producer, as an individual, a successful person with a successful career.

Some articles in the literature have discussed movie success (Simonton, 2009). Since films are both works of art and works of entertainment, it seems unanimous that cinematic success is not easily predicted. It is in fact commonly agreed that there is no definite "formula" one can follow to ensure success in the arts. However, a film's success can still be evaluated by a number of factors: critical evaluations (i.e., artistic merit as determined by movie goers and reviewers) both early and after the theatrical run, financial performance during opening weekend and gross, and movie awards for any aspect of the production. Despite identifying these "factors", making a profit in the film industry is nonetheless still hit or miss. It is hard to predict which films will succeed. It is even more difficult to make a successful film, and still more difficult to do so repeatedly. In fact, many studies cite legendary Hollywood producer William Goldman's famous remark that "nobody knows anything". In other words, while $1+1=2$ in many fields, there appears to be no similarly certain formula for success in the movie industry (Simonton, 2009).

Simonton (2009) also notes that most investigations into success in the arts have not been conducted by psychologists, but rather by economists and marketers. Interest has been focused almost entirely on the industry of entertainment as a whole, on a large scale, and very little on the individual participants as their own enterprise, for example, actors, singers, etc.

Based on a study in South Korea (Jung \& Kim, 2010), the appearance of a star in a movie increases the probability of a film's success by $15-19 \%$, and star power is higher than director power which contrasts with the Simonton $(2004 ; 2009)$ studies above. Yet, there is no discussion about what results in the success of the actor/entrepreneur.

There is some research noting the emergence of a new type of worker in the business world: the skilled independent professional, a designation which may ultimately relate to entertainers too (Van \& Van Witteloostuijn, 2013). The article does not discuss artists specifically, but it would seem that artists and entertainers could generally be described as "skilled independent professionals". Arguing that freelancers are both entrepreneurs and employees, this researcher calls this new type of worker a hybrid: They are entrepreneurs because they have to fight for work, but employees in that they typically work for a larger organization for a period of time, during which time they are obligated to work under the rule framework of the 
organization. These types of workers are known to have what is known as boundary-less careers (DeFillippi \& Arthur, 1998) where the freelancer is defined by Van and Van Witteloostuijn (2013) as "the archetypical job hopper, going from one project and employer to the next, never staying very long in a single organization" (p. 26). In a boundary-less career, a successful freelancer requires three things: first, individual expertise; second, knowledge of the career itself; and three, entrepreneurial knowledge. This lends credence to the proposition that successful entertainers, politicians, athletes, etc., are too but a form of successful businessman.

Several research articles do discuss what it takes to become a success in professional sports, a world similar to show business in that the players also perform and entertain. Of note is that success as an athlete is not an individual act (Cotton, Shen, \& Livne-Tarandach, 2011). There is talk of "developmental networks", that is, networks of people who support and guide the players. God was among "the developers" mentioned by research participants. So were teachers, friends, family, religious leaders, business associates, doctors, personal trainers, heroes, idols, peers, and even fans. Some of the roles that these individuals played in the development of the research participants' careers include: career strategizing, skill building, feedback, protection and preservation, sponsorship, acceptance and confirmation, counseling, emotional-support, friendship, inspiration, and motivation.

While coaching and skill development were the top two physical roles of the development network, the top psychological roles were emotional support, friendship, role modeling, inspiration, and acceptance. Interestingly, only $37.2 \%$ of the total support came from physical career development aspects; whereas $62.8 \%$ of the total support came from psychosocial aspects. In other words, the greatest support that these now successful athletes received from their networks was of a psychological nature. Indeed, both mentoring and involvement with informal networks (of colleagues, peers, etc.) have been linked to career success (Harris \& Ogbonna, 2006). However, the study focused narrowly on the roles of others, and not the decision-making of the individual athletes.

In another sports study, success (here defined as "peak performance") was based on just one factor: program (Harmison, 2006). In other words, regularly following a particular training program can methodically help take you from where you are on the field to where you want to be on the field. In many ways, this sounds like a business plan. However, even a perfect business plan alone does not ensure success.

Based on the Harmison (2006) study, it does seem that there is a unique psychological profile that correlates with peak performance processes in most athletes. Specifically, the desirable traits are: (a) high self-confidence and belief in success; (b) lots of energy but not overly stressed or tense; (c) a sense of being in control; (d) a feeling of being totally concentrated; (e) a focus clearly on the task at hand without extraneous thoughts; (f) positive thinking about the performance; (g) and high determination and commitment. However, this research discusses actual on-field/on-court performance - there is little study of the off-field psychological profile that got them onto the professional field in the first place.

One intriguing study did discuss what it takes to win in show business and what it took to win the Dutch Idol music competition (Zwaan \& ter Bogt, 2010). In the final analysis, those who started at a younger age, who had musical families, or who had taken music lessons had a greater likelihood of success. Social support from friends and family was also helpful, echoing the above study about the importance of networks.

Success for musicians in the Idols competition in the Netherlands was based on a number of criteria: having musical families; being prepared; dressing to impress; and curiously (though echoing the Noser and 
Zeigler (2014), Maltby (2010), and Greenwood, Long, and Dal Cin (2013) studies shared previously) having a high level of insecurity. Further, performance anxiety tended to make for better performances in that the performances themselves tended to be less dry and stilted. However, entering and winning a staged competition is different from the path most successful artists, entertainers, politicians, athletes, and entrepreneurs take, so this research may only be applicable to competition performers.

In this Dutch Idol study, the successful contestants actually had lower motivation than the unsuccessful ones, perhaps partly attributable to the fact that the Idol path to success is far different than the one where you create your own gigs or constantly go out and audition every day for projects after getting rejected time and time again. It is argued, therefore, that these Dutch Idol contestants perhaps had more extrinsic and social motivation to succeed rather than intrinsic motivation to succeed. Those following the traditional "beat the streets from the ground up" path to entertainment success may, on the contrary, have more intrinsic motivation to succeed. Buttressing this theory, many of the Dutch Idol contestants said they decided to join the competition just as an easy way to become famous. Very few of the contestants had planned out or prepared for a career in the arts (Zwaan \& ter Bogt, 2010).

Zwaan and ter Bogt (2010) remind us that to be successful in any field - and risky fields that can lead to fame through success are no exception - particular personality traits are required for that particular field. One such model linked to career success is The Big Five: conscientiousness; extraversion; agreeableness; openness to experience; and neuroticism (Goldberg, 2012). While neuroticism and agreeableness were both negatively correlated with career success, it is important to note that most studies using this model focused on corporate career success, and not on the higher risk pursuits of entertainment, entrepreneurship, politics, and athletics.

Finally, one study has noted that while small differences in talent may not keep you from becoming successful in entertainment, once you hit the star level, small differences in talent will have big effects on the amount of money you can earn at the highest levels (Rosen, 1981). In other words, while you do not need talent to become successful, apparently you do need that special "something" to become a superstar. The key here appears to be that stars with great talent become rare and precious commodities. In economic terms, "substitution between persons of varying talent is often easier when the products of their labor are homogeneous" (p. 453). For example, when starting out in show business, a great number of actors could equally well smile and say, "This is delicious!" for a soda commercial, but when looking for a leading actor to play the role of a psychologically traumatized individual for a feature film, the true choices for possible actors drop significantly.

\section{Success as a Component of This Study}

In general, a career success strategy can be defined as: "the sustained actions, behaviors, and accomplishments that are designed to enhance extrinsic or intrinsic career success" (Harris \& Ogbonna, 2006, p. 46). The issue at hand is that no test has ever attempted to determine scientifically what those sustained actions, behaviors, and accomplishments are.

For example, objective and subjective career success is based on Everett Hughes' 1937 and 1958 research (Gunz \& Heslin, 2005), but Hughes did not discuss what actually caused the success. Objective success is known as extrinsic success because it measures items that can be measured by almost any outside observer, that is, pay, position, promotion, and career progression. Subjective success is known as intrinsic success 
because these are all items that typically can only be measured by the individual under investigation, that is, work/life balance, emotional well-being, personal fulfillment, meaningful work, career satisfaction, and identity (Rode, Arthaud-Day, Mooney, Near, \& Baldwin, 2008). But what actions can one take to reach those pedestals?

According to Ituma, Simpson, Ovadje, Cornelius, and Mordi (2011), there are four factors affecting career success of either nature:

1. Human capital (i.e., experience, education, work history, etc.);

2. Demographic factors (i.e., age, race, sex, nationality);

3. Interpersonal process (i.e., mentoring and support); and finally

4. Organizational factors (i.e., the size of an organization, whether they are hiring, etc.).

However, this study was primarily focused on how to succeed in a corporate environment, and not risky ventures that can lead to fame, i.e., the type in which we are interested.

The Rode et al. (2008) study notes that these factors which determine career success may be different from the early stages of a career to the later stages. General mental ability (and the ability to learn) may provide a significant advantage in the early years of a career, whereas, administration, leadership, and decision-making skills may be more important during more senior levels of management. This is expected in that the more established a career becomes, the more different skills must be utilized, but how to measure your general competency in these domains and at the various "stages"?

Some studies have also shown that emotional intelligence (EI) can assist in leading one towards career success. EI is defined on four dimensions:

1. The ability to perceive emotions,

2. The ability to access and generate these emotions to assist thinking, and more importantly,

3. The ability to understand emotions and emotional knowledge, and

4. The ability to regulate emotions to promote learning and growth (Rode et al., 2008).

EI has been shown to be related to both long and short term performance; greater adaptability and flexibility; as well as positive social relationships. However, it is unclear to what extent one can increase ones current levels of EI. While a pro-active personality has a direct effect on career success, ability alone is not meaningful. The key, therefore (in all cases), is to combine high levels of motivation with the ability (Rode et al., 2008). But how to determine "high levels of motivation"?

Further, another study (Judge, Klinger, \& Simon, 2010) tends to show that ability (as also discussed above in the section on entertainment success) may not be very important on general entry level jobs. In other words, at the lower levels, basically anyone can do the job. The study found that initial career success may be based more on personality of an employee than on the ability of an employee, meaning that those with less talent but more appealing personalities may become the anointed "rising stars", leaving more talented but less appealing personalities at the starting gate because their talent never gets noticed or appreciated. Note, however, that this research article is not talking about "rising stars" in high risk ventures, but instead, rising stars within a business organization. However, the similarities are evident and it seems clear that one's personality plays a key role in one's success.

Lau and Shaffer (1999) argue five personality dimensions for career success, some of which have already been touched upon: locus of control; self-monitoring; self-esteem; optimism; and Machiavellianism. The more 
one has of each, the more one may tend to gravitate towards career success. However, others have recommended that managers should actively discourage clandestine career-advancing strategies and maneuvers, that is, Machiavellianism (Harris \& Ogbonna, 2006). In both cases, however, the studies focus on traditional careers, and not the more atypical risky ventures like the arts, entrepreneurship, politics, etc. Further, there is no comprehensive unified test to determine how all these factors inter-relate, so individuals are left to themselves to try to ascertain where they stand using multiple unrelated test questionnaires.

In one study of black nursing students, the successful students had a daily routine of consistent tasks they completed. Interestingly, few recognized these consistent tasks as a daily routine until it was brought to their attention (Muldoon \& Kremer, 1995). Having a daily routine or plan helped foster success because even if they could not stick to their plan consistently, they were at least able to stick to it most of the time. It gave the students a focus and a schedule, and this helped keep them on track, thus leading to success. Additionally, participating in study groups helped these nursing students to stay focused and motivated, and helped them to solve problems that they were unable to solve on their own. This again echoes studies mentioned earlier regarding the importance of networks. However, there does not appear to be a test to determine how one's focused daily routine impacts his or her success.

According to Srikanth and Israel (2012), those who exhibit high career commitment tend to have more career success. Career commitment is defined as "one's attitude towards one's profession or vocation" (Blau, 1985, p. 277). In more practical terms, career commitment is considered commitment to one's career goals in an active manner based on a plan. Anyone in any field with high career commitment tends to have a higher success rate. However, how to determine career commitment?

Today, due to the rare 20-year career in the same company in the same field, part of career commitment entails employee self-management (Kuijpers, Schyns, \& Scheerens, 2006). Employee self-management is something new in the last 20 years, requiring that players in the boundary-less career field (discussed earlier) take pro-active steps to ensure their continued relevance in the workplace.

The six main career competencies one needs, therefore, to successfully self-manage one's career are:

1. Career actualization ability (i.e., realizing career goals);

2. Career reflection (i.e., reflecting on one's competencies);

3. Motivation reflection (i.e., reflecting on one's desires and values);

4. Work exploration (i.e., reflecting on how best to use one's skills and competencies to benefit the organization);

5. Career control (i.e., the tendency to pursue additional learning and exploration); and

6. Networking (i.e., interacting with others).

This study's results show that the biggest factors influencing success were career actualization ability, career control, and networking. The study focused on career self-management, but that's assuming that the career already exists, and that the individual has already attained success. But how to get there in the first place?

Dispositional optimism is another key trait found in successful entrepreneurs. The belief that good things are coming in the future and the belief that bad things are not likely to occur are the two hallmarks of this type of optimism (Bozionelos, 2004). According to the small business administration, $85 \%$ of adults have considered starting their own business but only $12 \%$ have actually tried to do so. Part of this may be a lack of 
dispositional optimism in most people. Successful entrepreneurs all tend to have developed this dispositional optimistic outlook. An entrepreneur needs to be an eternal optimist, finding opportunity in every setback - and precisely because there are typically going to be many (often debilitating) setbacks from which to rebound. Can one easily determine whether they have the right optimistic nature to succeed in risky ventures?

A 2001 study of dozens of entrepreneurs (among those interviewed included Bill Gates, Ray Kroc, etc.) showed that "eternal optimism" was the one key mental process that was found in every single one of them (Boyett \& Boyett, 2001). Goal setting was another highly significant factor in ultimate financial performance of entrepreneurs. Successful entrepreneurs, therefore, tend to have three indispensable characteristics: They have dispositional optimism; are goal-oriented; and push forward despite all and any impediments and setbacks. However, is this the whole story?

A group of psychologist entrepreneurs were instead shown to have a number of process traits or skills in common, many of which have already been discussed: vision, drive, capital raising ability, concern with customer's needs, financial management skills, and self-promotion skills. Personally, they exhibited ambition, self-efficacy, determined optimism, self-confidence, decisiveness, a willingness to take risks, high ego resiliency, high tolerance for ambiguity, an ability to tolerate long period of deferred gratification, and a tendency to work hard (Bozionelos, 2004). But does an individual contain all of these traits, and is there a way to test it?

\section{Test Studies}

The closest related study that attempts to answer these questions appears to be a 2010 test called the Fame Interest Scale that was developed to identify a person's interest in fame, and its common corollary, success. However, it does not actually predict one's likeliness to find either success or fame, and does not help one maintain either once found (Maltby, 2010).

In other words, while there is research on what success and fame are, and while there is research on whether someone is oriented towards success and fame, no research has ever been conducted to predict success and fame. Further, no research has gone that one step further to actively provide a test solution that individuals can use to diagnose their potential for finding success and/or fame. Finally, no research to date has attempted to provide a statistically validated tool to provide individuals with a baseline from which to build on to improve one's likelihood of great success, and then potentially, fame.

Therefore, even though a number of studies have looked at factors associated with success and fame in high-risk/high-stakes activities, none has yet combined these factors into a test development study that is designed to predict success and fame, hence this endeavor.

\section{Creation of a Test to Predict Potential for Celebrity and Success Method}

\section{Generating Initial Items}

The current research was based upon a qualitative study of factors that contribute to success in highly competitive activities that have a potential for high levels of success (Mann, 2016). Grounded theory was used to extract themes from interviews of successful entertainers who were asked to describe the factors that contributed to their success. There were three phases to the process of achieving success: Orientation, Approach, and Maintenance. Within each phase, there were two to six major themes, for a total of 12 major themes or Axial Codes. There were two to seven subthemes, or Open Codes within each Axial Code. The initial 
instrument was conceptualized as having 12 scales, consistent with the Axial Codes. The two authors of the present study generated test items for each Axial Code, using the Open Codes as guides. The initial instrument included 186 items attitudinal items and 10 validity items.

\section{Participants}

Survey administration. The current test collected data from aspiring, practicing, and former artists, politicians, entrepreneurs, and athletes. An informed consent statement explained the nature and purpose of the research and that participation was voluntary and anonymous. It was explained that the participant would complete several hundred items online. The monetary reward of $\$ 1$ was mentioned when applicable. Researcher contact information was provided for questions and it was noted that participation could be discontinued at any time.

Participants were screened by an introductory statement that asked them to choose and describe their entertainment-related or creative career activity.

Data were collected online by posting links on Facebook and LinkedIn. Additional participants were solicited through Amazon Mechanical Turk (MTURK.COM). These participants received \$1.00 compensation for their participant. The final sample included 331 participants. The survey form was administered through SurveyMonkey.

The online survey form included the following:

- Participants were asked to rate 186 items on a one to nine scale, from "Completely disagree" to "Completely agree".

- Ten additional embedded items asked for a specific response on the one to nine response scale, i.e., "Show us you are paying attention. Please select 'Completely agree'". Surveys were discarded if a participant marked any of the 10 items incorrectly.

- Demographics, including sex, age, race, nationality, education, city of residence, income from the career activity, income from all sources, length of time pursuing the career activity.

- Level of fame (celebrity): Items asking whether the participant had been featured or interviewed by print and broadcast media and recognized in public by strangers as a result of the career activity. This was a six-item scale with Cronbach's alpha equal to 0.75 .

- Level of success and accomplishment (success): Items included, "I have had my share of great successes in this career activity". This was a nine-item scale with Cronbach's alpha equal to 0.89 .

- Financial support from career activity (money): Items asking the degree to which the career activity supports the participant's lifestyle. Sample item: "Over the last year, I have been able to pay all of my bills from money earned from this career activity, not including teaching”. This was a seven-item scale with Cronbach's alpha equal to 0.96 .

\section{Sample characteristics.}

Total N: 331 (after discarding surveys that did not meet the validity criterion)

Gender: $60.1 \% \mathrm{M}, 39.9 \% \mathrm{~F}$

Age: Mean 34.2 years, std. dev.: 11.0, range 20-79

Type of Activity $(\mathrm{n}=318)$ : 


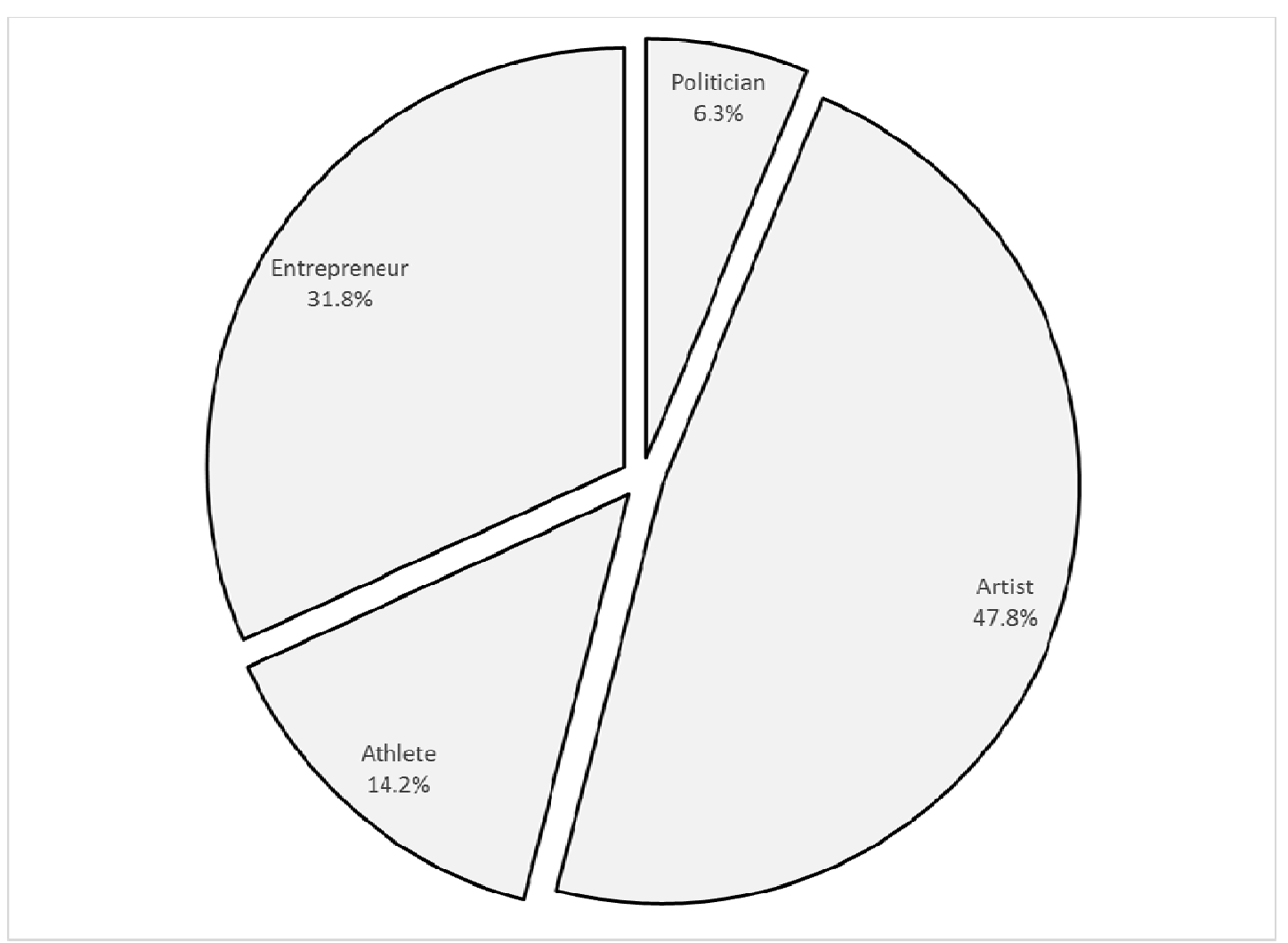

Figure 1. Types of activities.

Race/Ethnicity: $66.2 \%$ White, $16.0 \%$ Asian, 10.3\% Hispanic, 9.1\% Black, 1.8\% Other (totals to more than $100 \%$ because more than one category could be chosen)

Nationality: 62.8\% USA, 5.4\% India, 2.7\% Venezuela, 2.4\% Philippines, 2.4\% Canada, 24.2\% Other

Education: $78.5 \%$ college graduates; $26.8 \%$ graduate degree

\section{Results}

\section{Scale Refinement}

Items were selected to maximize scale internal consistency and to minimize scale inter-correlation. Factor analysis (principal axis factoring) was used to maximally distinguish the scales within each of the three phases; items associated with the Orientation, Approach, and Maintenance phases were analyzed separately. Direct oblimin rotation was applied and scree tests were used to determine the number of distinct factors in each of the three phases. Table 1 shows the factor loadings for scales within each phase. Within each phase, items have high loadings on their own scale and minimal loadings on the other scale(s), showing that the scales are measuring distinct constructs. The initial 12 scales were reduced to seven scales based on this analysis: two in the Orientation phase, two in the Approach phase, and three in the Maintenance phase. These seven scales and their characteristics are seen in Table 2. 
Table 1a

Factor Loadings for Items Within the Orientation Phase

\begin{tabular}{llll}
\hline & & \multicolumn{2}{c}{ Orientation phase } \\
\hline Items & & Doing what you love & Fame \\
\hline LOV01 & I feel "high" when I am doing the activity. & -0.12 \\
LOV02 & I feel excited when I think about doing the activity. & $\mathbf{0 . 7 5}$ & 0.09 \\
LOV03 & I love doing the activity. & $\mathbf{0 . 8 0}$ & 0.16 \\
LOV04 & I love pursuing this career. & $\mathbf{0 . 7 4}$ & $\mathbf{0 . 7 6}$ \\
LOV05 & I love doing what I have to do to achieve success in my field. & $\mathbf{0 . 6 8}$ & 0.09 \\
LOV06 & I push forward with this career despite criticism from others. & $\mathbf{0 . 5 7}$ & 0.08 \\
LOV07 & This activity is my “life calling". & $\mathbf{0 . 7 0}$ & 0.01 \\
LOV08 & I love telling people that this is who I am and what I do. & $\mathbf{0 . 7 3}$ & -0.17 \\
FAM01 & This activity wouldn't be worth the effort if I couldn't become famous. & 0.03 & $\mathbf{0 . 7 5}$ \\
FAM02 & Becoming famous from this activity is of utmost important to me. & -0.15 & $\mathbf{0 . 8 8}$ \\
FAM03 & I believe I am pursuing this career for the wrong reasons. & 0.20 & $\mathbf{0 . 7 2}$ \\
FAM04 & If I do not achieve fame and fortune, I will abandon the pursuit. & 0.10 & $\mathbf{0 . 7 7}$ \\
FAM05 & I just want to be famous, and the quicker the better! & -0.06 & $\mathbf{0 . 8 2}$ \\
\hline
\end{tabular}

Table $1 \mathrm{~b}$

Factor Loadings for Items Within the Approach Phase

\begin{tabular}{|c|c|c|c|}
\hline \multirow[b]{2}{*}{ Items } & & \multicolumn{2}{|c|}{ Approach phase } \\
\hline & & Determination & Focus \\
\hline DET1 & I am good at turning bad decisions into good results. & 0.71 & -0.09 \\
\hline DET2 & I take control of a bad situation and mold it to my advantage. & 0.74 & 0.00 \\
\hline DET3 & $\begin{array}{l}\text { I embrace, accept, and am able to handle emotionally exhausting psychological ups and } \\
\text { downs. }\end{array}$ & 0.73 & 0.05 \\
\hline DET4 & I am comfortable with change. & 0.68 & -0.02 \\
\hline DET5 & I can persist even after repeated rejections. & 0.70 & 0.12 \\
\hline DET6 & I am good at juggling many projects at the same time. & 0.67 & 0.01 \\
\hline DET7 & Thinking back on the last 10 years, I am willing to do what is necessary to succeed. & 0.66 & 0.08 \\
\hline DET8 & I am willing to give up things important to me in order to make it in this career. & 0.57 & -0.05 \\
\hline DET9 & Even when I feel down, I am still able to get important work done. & 0.69 & 0.12 \\
\hline DET10 & Rejection makes me feel more determined. & 0.63 & -0.13 \\
\hline DET11 & I am able to bounce out of any depressive mood in a relatively short period of time. & 0.73 & -0.04 \\
\hline DET12 & After being knocked down five times, I am the type of person who gets back up. & 0.61 & 0.07 \\
\hline DET13 & I'm good at finding the silver lining in every failure. & 0.77 & -0.01 \\
\hline FOC1 & As far as this career is concerned, I am unclear about where I'd like to be 5 years from now. & 0.16 & 0.54 \\
\hline FOC2 & Creating a long-term plan is foolish. & 0.15 & 0.62 \\
\hline FOC3 & I have close friends or family who often discourage me or disapprove of my career. & -0.09 & 0.67 \\
\hline FOC4 & I only have one source of income. & -0.11 & 0.62 \\
\hline FOC5 & I often find myself buying things I don't really need or can't really afford. & 0.13 & 0.68 \\
\hline FOC6 & I have difficulty getting my taxes in on time each year. & 0.04 & 0.72 \\
\hline FOC7 & Sometimes I make questionable decisions to make sure people are impressed with me. & -0.12 & 0.69 \\
\hline
\end{tabular}


Table 1c

Factor Loadings for Items Within the Maintenance Phase

\begin{tabular}{|c|c|c|c|c|}
\hline \multirow[b]{2}{*}{ Items } & & \multicolumn{3}{|c|}{ Maintenance phase } \\
\hline & & $\begin{array}{l}\text { Business } \\
\text { skills }\end{array}$ & Maverick & $\begin{array}{l}\text { Lifelong } \\
\text { learner }\end{array}$ \\
\hline BUS01 & I push forward against all odds with military doggedness and determination. & 0.58 & 0.25 & -0.12 \\
\hline BUS02 & I plan my moves, and then I execute. & 0.66 & -0.01 & 0.09 \\
\hline BUS03 & I am able to see the big picture and also the small details at the same time. & 0.57 & -0.01 & 0.12 \\
\hline BUS04 & I have unwavering self-determination, despite the situation. & 0.60 & 0.15 & 0.12 \\
\hline BUS05 & I create measurable benchmarks to gauge my success rate. & 0.41 & -0.01 & 0.26 \\
\hline BUS06 & I nearly always meet crucial project deadlines. & 0.65 & -0.01 & -0.06 \\
\hline BUS07 & I always show up on time. & 0.57 & -0.13 & -0.03 \\
\hline BUS08 & People consider me as someone who gets things done and done well. & 0.70 & 0.10 & -0.02 \\
\hline BUS09 & I am good at negotiating the basic terms of a contract with a potential partner. & 0.61 & 0.11 & 0.12 \\
\hline BUS10 & I use written contracts to make clear what I expect from my career associates. & 0.48 & 0.07 & 0.18 \\
\hline BUS11 & I know my strengths and weaknesses very well. & 0.61 & -0.05 & 0.18 \\
\hline BUS12 & I can do basic accounting and can write a good press release. & 0.51 & 0.07 & 0.14 \\
\hline BUS13 & I am an organized person. & 0.76 & -0.11 & -0.03 \\
\hline BUS14 & People consider me organized. & 0.81 & -0.05 & -0.12 \\
\hline MAV01 & I like to take risks with my career if there is a chance the risks will pay off. & 0.17 & 0.57 & 0.04 \\
\hline MAV02 & Sometimes I need to break the rules to get ahead in my career. & -0.09 & 0.64 & 0.03 \\
\hline MAV03 & I like taking big risks that could succeed massively. & 0.10 & 0.56 & 0.17 \\
\hline MAV04 & I have broken rules and been a rebel to promote my success. & -0.03 & 0.78 & -0.08 \\
\hline LRN01 & I strive for continual improvement in my activity and related disciplines. & 0.31 & -0.05 & 0.48 \\
\hline LRN02 & $\begin{array}{l}\text { To improve my skills in my activity and related disciplines, I spent money this } \\
\text { last year on educational classes, workshops, books, or training materials. }\end{array}$ & -0.06 & 0.16 & 0.52 \\
\hline LRN03 & I consider myself a lifelong learner. & 0.26 & -0.09 & 0.49 \\
\hline LRN04 & $\begin{array}{l}\text { The more I learn about my activity, the more I realize how much more I need to } \\
\text { know. }\end{array}$ & -0.05 & -0.11 & 0.78 \\
\hline LRN05 & I like reading books about how to manage and grow my career. & -0.01 & 0.12 & 0.60 \\
\hline LRN06 & I regularly ask others for their advice and feedback. & 0.08 & -0.02 & 0.50 \\
\hline LRN07 & I often take the good advice of others, even if it scares me. & 0.09 & 0.20 & 0.38 \\
\hline
\end{tabular}

Table 2

Scale Characteristics

\begin{tabular}{lllllll}
\hline Phase & Scale name & Items & Alpha & Mean & Std. Dev. & Skewness \\
\hline \multirow{2}{*}{ Orientation } & Doing what you love & 8 & 0.86 & 6.97 & 1.32 & -0.58 \\
& Desire for fame & 5 & 0.86 & 6.61 & 1.96 & -0.55 \\
\multirow{3}{*}{ Approach } & Determination & 13 & 0.90 & 6.52 & 1.27 & -0.47 \\
& Focus & 7 & 0.78 & 5.95 & 1.64 & -0.17 \\
\multirow{3}{*}{ Maintenance } & Business skills & 14 & 0.91 & 6.64 & 1.27 & -0.36 \\
& Maverick & 4 & 0.74 & 5.67 & 1.66 & -0.28 \\
& Lifelong learner & 7 & 0.78 & 6.55 & 1.32 & -0.67 \\
\hline
\end{tabular}


Validity and Scale Intercorrelations

Table 3 shows the correlations between the scales.

Table 3

Scale Intercorrelations

\begin{tabular}{llllllll}
\hline & $\begin{array}{l}\text { Orient } \\
\text { OR1: } \\
\text { What you }\end{array}$ & $\begin{array}{l}\text { OR2: } \\
\text { Desire } \\
\text { for fame }\end{array}$ & $\begin{array}{l}\text { AP1: } \\
\text { Determination }\end{array}$ & $\begin{array}{l}\text { AP2: } \\
\text { Focus }\end{array}$ & $\begin{array}{l}\text { MA1: } \\
\text { Business }\end{array}$ & $\begin{array}{l}\text { MA2: } \\
\text { Maverick }\end{array}$ & $\begin{array}{l}\text { MA3: } \\
\text { Lifelong } \\
\text { learner }\end{array}$ \\
\hline OR1 Orient: What you love & 1.00 & 0.20 & 0.59 & 0.25 & 0.49 & 0.21 & 0.47 \\
OR2 Orient: Desire for fame & & 1.00 & 0.12 & 0.71 & 0.15 & -0.22 & 0.16 \\
AP1 Approach: Determination & & & 1.00 & 0.24 & 0.73 & 0.39 & 0.56 \\
AP2 Approach: Focus & & & & 1.00 & 0.30 & -0.22 & 0.17 \\
MA1 Maintain: Business & & & & & 1.00 & 0.25 & 0.57 \\
MA2 Maintain: Maverick & & & & & & 1.00 & 0.31 \\
\hline
\end{tabular}

Correlations were calculated between each of the scales and measures of career success. The "Success" measure contains nine items and looks at self-reported career satisfaction and success, i.e., "I feel like I have accomplished almost everything I have wanted for myself in this career activity". "Celebrity" is a six-item measure of fame, including media mentions and public recognition (i.e., "Have you ever appeared in a national magazine?"). "Money" is a measure of the degree to which participants can support themselves and their families from their career activity. Table 4 supports scale validity and shows the following relationships:

Table 4

Validity Coefficients

\begin{tabular}{llllllllll}
\hline Scale & Success & Celebrity & Money & Age & Education & $\begin{array}{l}\text { Career } \\
\text { income }\end{array}$ & $\begin{array}{l}\text { All } \\
\text { income }\end{array}$ & $\begin{array}{l}\text { How long career } \\
\text { income }\end{array}$ \\
\hline OR1 Orient: What you love & $0.20^{*}$ & $0.24^{*}$ & 0.01 & 0.13 & -0.01 & -0.07 & 0.01 & $0.21^{*}$ & -0.04 \\
OR2 Orient: Desire for fame & $0.36^{*}$ & $0.16^{*}$ & $0.23^{*}$ & $-0.34^{*}$ & 0.12 & 0.12 & -0.12 & $-0.19^{*}$ & $0.29^{*}$ \\
AP1 Approach: & $0.35^{*}$ & $0.24^{*}$ & $0.16^{*}$ & $0.18^{*}$ & 0.01 & 0.13 & $0.19^{*}$ & $0.23^{*}$ & 0.04 \\
$\begin{array}{l}\text { Determination } \\
\text { AP2 Approach: Focus }\end{array}$ & -0.13 & -0.10 & -0.05 & $0.31^{*}$ & -0.10 & -0.02 & $0.24^{*}$ & $0.22^{*}$ & $-0.26^{*}$ \\
MA1 Maintain: Business & $0.32^{*}$ & $0.17^{*}$ & 0.14 & $0.15^{*}$ & 0.05 & 0.09 & $0.15^{*}$ & $0.17^{*}$ & 0.01 \\
MA2 Maintain: Maverick & $0.33^{*}$ & $0.25^{*}$ & 0.08 & -0.01 & 0.08 & $0.16^{*}$ & 0.06 & 0.06 & 0.16 \\
MA3 Maintain: Lifelong & 0.13 & 0.13 & 0.03 & 0.08 & 0.08 & 0.00 & 0.04 & 0.07 & 0.00 \\
learner & & & & & & & & &
\end{tabular}

Note. ${ }^{*} \mathrm{p}<0.01$.

The three phases (success orientation, success approach, and success maintenance) were derived from the original grounded theory study, and then tested and validated through the current study, as follows:

\section{Success Orientation (OR).}

OR1—Doing what you love: Doing "what you love" is associated with greater success and celebrity. This score is higher for individuals engaged in their activity longer.

OR2 - Seeking fame: Seeking fame is associated with greater success, celebrity, and more financial attainment. There is less focus on attaining fame among those who are older and those who have practiced their activity longer. 


\section{Success Approach (AP).}

AP1-Determination: Determination is associated with greater success, celebrity, and money. It is higher among participants who are older and who have practiced their activity longer. It is associated with higher overall income, but not specifically with income from the activity.

AP2 - Focus: Greater focus is associated with age and with longer practice of the activity. It is associated with greater total income, but not associated with income specifically from the activity.

\section{Success Maintenance (MA).}

MA1-Business orientation: A business orientation is associated with greater success and celebrity. It is higher among participants who are older and who have practiced their activity longer. It is associated with higher overall income, but not specifically with income from the activity.

MA2-Maverick: Being a "Maverick" or risk-taker is associated with greater success and celebrity. It is the only scale associated with greater income from the activity specifically.

MA3 - Lifelong learner: Being a "lifelong learner" is not associated with any of the validity criteria.

Table 5

Multiple Regression Formulas

\begin{tabular}{llll}
\hline & \multicolumn{3}{c}{ Success } \\
\cline { 2 - 4 } & Beta & $\mathrm{t}$ & Significance \\
\hline OR2 Orient: Desire for fame & 0.501 & 7.723 & $<0.001$ \\
AP1 Approach: Determination & 0.184 & 2.613 & 0.009 \\
Education & 0.122 & 2.653 & 0.008 \\
Age & 0.126 & 2.585 & 0.010 \\
MA1 Maintain: Business & 0.158 & 2.337 & 0.020 \\
MA2 Maintain: Maverick & 0.129 & 2.471 & 0.014 \\
AP2 Approach: Focus & 0.133 & 1.974 & 0.049 \\
\hline & & & Celebrity \\
& Beta & $\mathrm{t}$ & Significance \\
\hline MA2 Maintain: Maverick & 0.149 & 2.761 & 0.006 \\
OR1 Orient: What you love & 0.233 & 4.341 & $<0.001$ \\
Education & 0.140 & 2.707 & 0.007 \\
OR2 Orient: Desire for fame & 0.207 & 3.615 & $<0.001$ \\
Age & 0.153 & 2.799 & 0.005 \\
\hline & & & Money \\
\cline { 2 - 4 } & Beta & $\mathrm{t}$ & Significance \\
\hline OR2 Orient: Desire for fame & 0.360 & 4.892 & $<0.001$ \\
AP1 Approach: Determination & 0.155 & 2.870 & 0.004 \\
AP2 Approach: Focus & 0.182 & 2.422 & 0.016 \\
Gender (M = 1, F = 2) & -0.126 & -2.393 & 0.017 \\
\hline
\end{tabular}

Stepwise regression then calculated formulas to best estimate the three measures of success from the seven test scores. Gender, ethnicity (White vs. Non-white), age, and education were also entered along with the predictor variables. $P$ to enter the equation was $0.05 ; p$ to exit was 0.10 .

The multiple R correlations were 0.596, 0.416, and 0.349 for prediction of Success, Celebrity, and Money respectively. These are the multiple correlations associated with the regression formulas in Table 5 and indicate the degree to which the combination of variables can predict the criterion variable. These formulas show Betas, 
the standardized weights that would be used to predict standardized criteria (converted to z-scores) from standardized test scores. For instance, higher Success scores are predicted by higher scores on the Determination, Business, Maverick, Seeking Fame, and Focus scales. Participants who were older and more educated tended to score higher on the Success scale. The multiple correlation of 0.596 can be squared to indicate the percent of variance explained; $35.5 \%$ of the variation in Success can be explained or predicted by a combination of these test scores. The U.S. Department of Labor (2006) provides guidelines for interpreting validity coefficients. They note that a value "above 0.35 " is "very beneficial" and values from " 0.21 to 0.35 " are "likely to be useful". P-values for each of the three regression formulas are less than 0.001, F(7,322) $=25.34$ for Success, $F(5,324)=13.52$ for Celebrity, and $\mathrm{F}(4,325)=11.27$ for Money.

\section{Discussion}

This study, initiated through qualitative grounded theory study and finalized through a quantitative analysis, has helped to show that elusive success and fame attainment can be broken down into three phases, Orientation, Approach, and Maintenance, and that certain individuals are better positioned for initial and long-term success based on how well they have developed their individual characteristics in each of the three phases. In the present research, we developed a psychometric instrument that predicts self-reported success and fame attainment from scores on attitudinal scales.

In the present study, we collected an anonymous, online sample from aspiring, practicing and former artists, politicians, entrepreneurs, and athletes. We used self-report measures of career success, including a measure of "celebrity", which asked if the participant had been featured or interviewed by print and broadcast media and recognized in public by strangers as a result of the career activity. We found that higher levels of reported celebrity and self-appraisals of success in the career activity are associated with a greater desire for fame, risk-taking or "Maverick" tendencies, and a passion for the career activity. Celebrity and Success are also more likely to be found among individuals who are older and have more formal education. Success was additionally associated with career focus and determination. Finally, the degree to which individuals can support themselves from the career activity is associated with desire for fame, focus, and determination and is higher among men than women.

Past research has looked at desire for fame and success in highly competitive fields as possibly pathological and at least as ways to compensate for low self-esteem or personal deficiencies. The present study sets out on a different tack, looking at positive traits and attitudes that might promote success. This perspective is consistent with the increasing trend toward positive psychology and away from pathologizing human behavior (Seligman \& Csikszentmihalyi, 2000).

This test has practical application in success coaching. These scales can also be useful to talent managers, talent agents, producers, athletic coaches, campaign managers, business advisors, accountants, and other managers of talent, to help develop and nurture careers. For example, if any scores are low, the factors therein need to be analyzed and improved, to increase the scores, and thus, the likelihood of success.

This study is only an initial foray into the prediction of success. As such, it has several limitations. Using an online, anonymous sample afforded the opportunity to reach many geographically and otherwise diverse individuals. Participants provided extensive information and the anonymity allowed them to feel free to reveal personal details. On the other hand, this research depended on unverified self-report measures of success, and so the accuracy of these reports was not guaranteed. It is also unlikely to have tapped into individuals who 
would be considered true celebrities, and so the range of our criterion variables was limited. Finally, the research survey was only available to internet users, which could eliminate or reduce the likelihood of including certain types of individuals.

This test fills a void and could potentially help individuals on their ambitious journeys. Its primary purpose is to provide direction and feedback to those who are seeking success in a risky field, and to provide continued direction and feedback to those who are already successful and who want to do all that is possible to ensure success already attained is maintained for the foreseeable future. It looks at celebrity and success in a new light, as characteristics that can be predicted from attitudinal variables.

Some areas for future research include:

- Determining to which other careers domains this test can apply through additional sampled and controlled test taking.

- Creating a longitudinal study, with a control group, over five to ten years, to determine if those who take the test on a bi-annual basis tend to pursue the career longer, and find greater success, than those in the control group, who do not take the test or follow the recommendations.

- Creating a longitudinal study, with a control group, over five to ten years, to determine if those who work regularly with a mentor trained in the disciplines of the three phases tend to pursue the career longer, and find greater success, than those in the control group, who do not take the test, or who do, but do not work with a trained mentor.

- Including individuals who have attained high levels of success in competitive fields to determine whether the test's predictions extend beyond the limited range assessed.

- Using means other than self-report to determine success, using, for instance, a sample derived from a reference such as Who's Who.

\section{References}

American Psychological Association. (2012). Division spotlight: Members discuss the creation of two new divisions. Monitor on Psychology, 43(9), 8.

Blau, G. J. (1985). The measurement and prediction of career commitment. Journal of Occupational Psychology, 58, $277-288$. doi:10.1111/j.2044-8325.1985.tb00201.x

Boyett, J., \& Boyett, J. (2001). The guru guide to entrepreneurship. New York: Wiley.

Bozionelos, N. (2004). The relationship between disposition and career success: A British study. Journal of Occupational \& Organizational Psychology, 77(3), 403-420.

Cotton, R. D., Shen, Y., \& Livne-Tarandach, R. (2011). On becoming extraordinary: The content and structure of the developmental networks of major league baseball hall of famers. Academy of Management Journal, 54(1), 15-46. doi:10.5465/AMJ.2011.59215081

DeFillippi, R. J., \& Arthur, M. B. (1998). Paradox in project-based enterprise: The case of film making. California Management Review, 40(2), 125-139. doi:10.2307/41165936

Evans, J. S. B. T., \& Thompson, V. A. (2004). Informal reasoning: Theory and method. Canadian Journal of Experimental Psychology/Revue Canadienne De Psychologie Expérimentale, 58(2), 69-74. doi:10.1037/h0085797

Fernbach, P. M., Darlow, A., \& Sloman, S. A. (2011).Asymmetries in predictive and diagnostic reasoning. Journal of Experimental Psychology: General, 140(2), 168-185. doi:10.1037/a0022100

Goldberg, E. L. (2012). The changing tides of careers. People \& Strategy, 35(4), 52-58.

Greenwood, D., Long, C. R., \& Dal Cin, S. (2013). Fame and the social self: The need to belong, narcissism, and relatedness predict the appeal of fame. Personality and Individual Differences, 55(5), 490-495.

Gunz, H. P., \& Heslin, P. A. (2005). Reconceptualizing career success. Journal of Organizational Behavior, 26(2), 105-111. doi:10.1002/job.300 
Harmison, R. J. (2006). Peak performance in sport: Identifying ideal performance states and developing athletes' psychological skills. Professional Psychology: Research and Practice, 37(3), 233-243. doi:10.1037/0735-7028.37.3.233

Harris, L. C., \& Ogbonna, E. (2006). Approaches to career success: An exploration of surreptitious career-success strategies. Human Resource Management, 45(1), 43-65.

Hill, A., Collier-Baker, E., \& Suddendorf, T. (2012). Inferential reasoning by exclusion in children (homo sapiens). Journal of Comparative Psychology, 126(3), 243-254. doi:10.1037/a0024449

Ituma, A., Simpson, R., Ovadje, F., Cornelius, N., \& Mordi, C. (2011). Four “domains” of career success: How managers in Nigeria evaluate career outcomes. International Journal of Human Resource Management, 22(17), 3638-3660. doi:10.1080/09585192.2011.560870

Jayson, S. (2007). Generation Y's goal? Wealth and fame. USA Today, Jan. 11, 2007.

Judge, T. A., Klinger, R. L., \& Simon, L. S. (2010). Time is on my side: Time, general mental ability, human capital, and extrinsic career success. Journal of Applied Psychology, 95(1), 92-107. doi:10.1037/a0017594

Jung, S.-C., \& Kim, M. H. (2010). Does the star power matter? Applied Economics Letters, 17(11), $1037-1041$. doi:10.1080/00036840902817490

Kolstad, I., \& Wiig, A. (2013). Is it both what you know and who you know? Human capital, social capital and entrepreneurial success. Journal of International Development, 25(5), 626-639. doi:10.1002/jid.2904

Kuijpers, M. A. C. T., Schyns, B., \& Scheerens, J. (2006). Career competencies for career success. Career Development Quarterly, 55(2), 168-178.

Lau, V., \& Shaffer, M. (1999). Career success and the effects of personality. Career Development International, 4(4), $225-231$.

Maltby, J. (2010). An interest in fame: Confirming the measurement and empirical conceptualization of fame interest. British Journal of Psychology, 101(3), 411-432.

Mann, M. (2016). Succeeding as an entertainer: The experiences and descriptions of the process of reasoning used in shaping career aspirations for the successful entertainer: A grounded theory study (ProQuest Dissertations, Capella University, Minneapolis, Minnesota, United States).

Meyer, P., Dighe, A., \& Van Epps, J. (2014). The actor's opportunity—strategies from successful executives. B > Quest, 1-7.

Mucha, R. T. (2005). Business as performance art: Are you getting rave reviews? Organization Development Journal, $23(3), 67-72$.

Muldoon, O. T., \& Kremer, J. (1995). Career aspirations, job satisfaction and gender identity in female student nurses. Journal of Advanced Nursing, 21(3), 544-550. doi:10.1111/j.1365-2648.1995.tb02739.x

Noser, A., \& Zeigler, V. (2014). Self-esteem instability and the desire for fame. Self and Identity, 13(6), 701-713.

O'Brien, E., \& Hagen, L. (2013). The thrill of (absolute) victory: Success among many enhances emotional payoffs. Emotion, 13(3), 366-374. doi:10.1037/a0032041

Peterson, S. S. (2014). Award-winning authors and illustrators talk about writing and teaching writing. Reading Teacher, 67(7), 498-506. doi:10.1002/trtr.1249

Rode, J. C., Arthaud-Day, M., Mooney, C. H., Near, J. P., \& Baldwin, T. T. (2008). Ability and personality predictors of salary, perceived job success, and perceived career success in the initial career stage. International Journal of Selection \& Assessment, 16(3), 292-299. doi:10.1111/j.1468-2389.2008.00435.x

Rosen, S. (1981). The economics of superstars. The American Economic Review, 71(5), 845-858.

Screen Actors Guild. (2004). 2004 casting date report overview. Retrieved from http://www.sagaftra.org/content/2004-casting-data-report-overview

Seligman, M., \& Csikszentmihalyi, M. (2000). Positive psychology: An introduction. American Psychologist, 5(1), 5-14.

Simonton, D. K. (2004). Film awards as indicators of cinematic creativity and achievement: A quantitative comparison of the Oscars and six alternatives. Creativity Research Journal, 16(2), 163-172. doi:10.1207/s15326934crj1602\&3_2

Simonton, D. K. (2009). Cinematic success criteria and their predictors: The art and business of the film industry. Psychology \& Marketing, 26(5), 400-420.

Srikanth, P. B., \& Israel, D. (2012). Career commitment \& career success: Mediating role of career satisfaction. Indian Journal of Industrial Relations, 48(1), 137-149.

Sternberg, R. J. (1999). The theory of successful intelligence. Review of General Psychology, 3(4), $292-316$. doi:10.1037/1089-2680.3.4.292

Sternberg, R. J. (2003). A broad view of intelligence: The theory of successful intelligence. Consulting Psychology Journal: Practice and Research, 55(3), 139-154. doi:10.1037/1061-4087.55.3.139

Union Facts. (2013). Screen actors guild. Retrieved from http://www.unionfacts.com/union/Screen_Actors 
U.S. Department of Labor. (2006). Testing and assessment: A guide to good practices for workforce investment professionals. U.S. Department of Labor Employment and Training Administration. Retrieved from https:/wdr.doleta.gov/directives/attach/TEN/ten2007/TEN21-07a1.pdf

Van, D. B., \& Van Witteloostuijn, A. (2013). Drivers of freelance career success. Journal of Organizational Behavior, 34(1), 24-46. doi:10.1002/job. 1786

Zwaan, K., \& ter Bogt, Tom F. M. (2010). From zero to hero: An exploratory study of the predictors of success in the Dutch idols competition. Popular Music \& Society, 33(3), 319-337. doi:10.1080/03007760903392708 